\title{
Activated sludge biocenosis regulation for intensifying aerating constructions
}

\author{
Nazira Dzhumagulova ${ }^{1,2}$, Ivan Gavrilov ${ }^{2}$ and Dinh Dap Nguyen ${ }^{1, *}$ \\ ${ }^{1}$ Moscow State University of Civil Engineering, Yaroslavskoe shosse, 26, Moscow, 129337, Russia \\ ${ }^{2}$ Russian State Agrarian University - MSHA named after K.A.Timiryazev, Timiryazevskaya ulisa, 49, \\ Moscow, 127550, Russia
}

\begin{abstract}
One of the most effective methods of wastewater treatment is a biochemical method that almost completely disposes various dissolved organic matter. To improve the oxidation capacity of aerotanks and to control the biochemical processes of wastewater treatment, it was necessary to determine experimentally biocenosis variability influenced by the environment and other factors. The goal of the present research is intensification of biological wastewater treatment by means of direct effect upon the metabolism of activated sludge microorganisms. The experiment studied the organization of species and quantitative composition of active sludge biocenosis in aerotanks while removing contaminants from wastewater. The experiments were carried out in continuous-flow aerotanks of publicly owned treatment facilities. Everyday over a period of three weeks, samples of microorganisms were obtained from aerotanks, quality and quantity objectives of purified water.
\end{abstract}

\section{Introduction}

Up to now, there is no perfect system of bioindicator for biological wastewater treatment. While removing certain substances from wastewater during treatment, species composition of activated sludge changes successively. Biocenosis transition from one developmental stage to another depends on the amount of nutrients in the medium, that is, in activated sludge process with BOD load per $1 \mathrm{~g}$ of ash-free basis. It follows by including more perfective species in biocenosis. Depending on wastewater composition, activated sludge biocenosis can be characterized by high species diversity - up to 45 species of protozoa, with a different numerical predominance of individual species. Nowadays, the aerotanks used for treatment of domestic and industrial sewage have technically exhausted their potentials for intensification of biological treatment of wastewater

As a result of solution of these models, the following recommendations:

- Constructions of complex multifunctional treatment facilities including equipment of different functions and operating principles.

- Method of biological wastewater treatment by means of direct effect upon the metabolism of activated sludge microorganisms is the most advanced and nearly inexhaustible

\footnotetext{
* Corresponding author: nguyendinhdap@gmail.com
} 
- Knowledge of the processes occurring in activated sludge, allows to identify impact factors and make prediction in the process of water treatment and, consequently, control it.

\section{Review of literature}

In many cities and small towns of Russia, municipal treatment facilities were constructed in 60-70 of the last century. They exhausted their resources, became outdated morally and physically and demand reconstruction. Besides, environment-oriented regulatory actions specify more stringent requirements to emptying effluent sewage [2].

The authors researches conducted biofilm on biofilters with various loading materials to remove nitrogen compounds from sewage in the laboratory. They obtained the results on ammonium nitrogen and other indices necessary for dumping into fishery waters, but biofilters are mainly intended for small sewage facilities [3]. All the organisms that enter the activated sludge biocenosis are also enter the living biofilm biocenosis. However, the ratio of organisms in biofilters is absolutely different from that in the activated sludge.

Nowadays, reagent and membrane technologies are widely used for industrial sewage treatment. These technologies lead to increase in cost of sewage treatment, in addition, chemical wastes are formed, the distribution of which has a negative impact on the natural environment. Different chemical, physical and chemical, mechanical and biological methods are applied in sewage treatment. However, being the most widespread and economic, biological method of water treatment is preferable. One of the main pollutants in textile production is Synthetic Surfactants. The main sources of supply of Synthetic Surfactants (SS) are sewage from washing plants, its also present in many industries [4].

The results of experiments show that in order to reduce concentration of SS to required indices, biological methods of water treatment on aerotanks are quite effective. To operate biochemical process of water treatment and to considerably intensify it, one must know the role of its determining factors: the structure of microorganisms and their biochemical properties at different stages of water treatment, the interaction of separate groups of microbes and with more high-organized groups of organisms effect of medium conditions (composition and concentration of sewage, temperature, $\mathrm{pH}$ ), environmental variability and other factors.

\section{Materials and methods}

To increase the efficiency of aeration constructions and coltrol biochemical treatment processes it is necessary to do the following tasks:

1) The analysis of qualitative and quantitative indices of sewage treatment in continuousflow aerotanks considering biocenosis composition;

2) A research of structure and composition of ferments formed as a result of treatment;

3) Recommendations on intensification of aerotanks in biological methods of sewage treatment.

Continuous-flow aerotanks for full-scale biological treatment were chosen for the research. Aerotank average sewage flow rate is 50 thousand $\mathrm{m} 3 /$ day, average dose of aerotank mixed liquor is $1,5 \mathrm{mg} / 1$, dissolved oxygen level is $2,7 \mathrm{mg} / 1$, sludge index is 87 .

Temperature 21,70C. Within 21 days the samples were taken daily from clear water after primary treatment, before water intake in aerotank. The retention time of clarified water in an aerotank makes 6 - 7 hours; therefore, treated water samples were taken in the second half of day. Besides water treatment indices, the structure and species composition of sludge in renovated water was also under research. For evaluation quality of treated in clarified and purified water, samples were taken according to following indices - suspended substance, oil 
products, surfactants, phosphates and ammonium salts nitrogen. The results are given below in a form of schedules and tables.

Calculation of organisms is made by microscopy. After calculation of all microfauna, the following indices are calculated: species quantity, the ratio of the attached microorganisms to freely floating (coefficient $\mathrm{K}$ ), percentage of susceptible microorganisms to persistent ones, the Cuba index (it involves the information about both the number of species and about their numerical distribution by species) and quantity of microorganisms on a sludge dose [5].

1. The ratio of the attached microorganisms to freely floating (coefficient $K$ ), $K=A / B$, where A - the attached microorganisms, B - freely floating microorganisms

2. Percentage of susceptible microorganisms to persistent ones

3. Quantity of microorganisms on a sludge dose, $\mathrm{C}=\mathrm{X} / \mathrm{Vkap} \times \mathrm{m}$, where $\mathrm{C}$ - quantity of organisms in a sample, $\mathrm{X}$ - quantity of specimens, $\mathrm{V}$ - the drop volume $(0,01 \mathrm{ml}), \mathrm{m}$ - a sludge dose by weight

4. The index Cuba, $\mathrm{D}=\mathrm{N}+\mathrm{V}$, where $\mathrm{N}$ - quantity of species, $\mathrm{V}$ - unit of equal distribution

\section{Results}

The hydrobiological analysis of activated sludge samples selected from aerotank showed rich species composition of about 37 types. The development of zoogleal bacterial clumps and mesosaprobic protozoas is characteristic of the aerotanks working for complete treatment.

Table 1. The quantitative and qualitative composition of activated sludge biocenosis.

\begin{tabular}{|c|c|c|c|c|c|}
\hline Name & Quantity & Name & Quantity & Name & $\begin{array}{c}\text { Quan } \\
\text { tity }\end{array}$ \\
\hline Aspidiscacostata & 714 & Vorticellanutens & 143 & Mastigamaeba & 71 \\
\hline Chilodoncuculus & 214 & Zoothamniumsp & 286 & Amaebaproteus & 143 \\
\hline Amphileptusclap & 0 & Thuricolasimiles & 214 & Amaebamedium & 143 \\
\hline Litonotuscarinatus & 0 & Podophriafixa & 0 & Colurellasp & 214 \\
\hline Spirostomumambigu & 71 & Tokophryamollis & 0 & Rotariarotatoria & 357 \\
\hline Colepshirtus & 214 & Arcellavulgaris & 857 & Philodinasp & 71 \\
\hline Chaetonotusmax & 143 & Centropixisaculeat & 0 & Lecaneinermis & 143 \\
\hline Epistvlisrotens & 1500 & Centropixissp & 286 & Aeolosomahemprichi & 429 \\
\hline Epistylisplicatilis & 429 & Pamphagushyalin & 71 & Zoogloeauva & 571 \\
\hline Opercullariacooarc & 0 & Eugliphaacanthop & 143 & Actinomycetes & 0 \\
\hline Vorticellaalba & 71 & Bodoglobosus & 357 & Flamentous bacteria & 71 \\
\hline Vorticellacovallaria & 357 & Flagellatasp & 571 & & \\
\hline
\end{tabular}

The activated sludge biocenosis is a flexible natural mechanism allowing the compound waste mediumwith structural heterogeneity inherent in it to provide the most efficient distribution of substances through structural change of microorganisms. Every time, with a change of loading parameters, the system is forced to select the most efficient configuration of interaction with the external environment due to the processes of self-organization optimizing this interaction.

Fig. 1 shows the species composition of the activated sludge on 26.06.2017, the quantitative parameters are presented in table 1. A thorough analysis of species diversity led to the assessment of activated sludge biocenosis. Then the number of species in a carefully mixed sample was counted by microscopy. The sum of each separate species in 1 drop $(0,01$ $\mathrm{ml}$ ) is to be entered in the table1. A great variety of microorganisms, and at the same time their irregular distribution depends on a sewage flow rate, sewage composition and concentration, temperature, $\mathrm{pH}$. Due to the large amount of data per each day, experimental data are presented for one day. The experiments stand that maintaining stable key parameters of facilities such as sewage flow rate and BOD loading, forms a certain composition of activated sludge biocenosis. Different types of bacteria, infusoria, rotifer worms etc are a part of activated sludge. In our case, the following species of microorganisms prevail: 
- Protozoan - Amoeba - naked amoebas. Their lowest forms have no skeleton and represent a naked flock of cytoplasm;

- Infusorias - Vorticellacovallaria - individual infusorians. They fall into a class of the most high-organized representatives of protozoa, which move with the help of cilia, short trichoid outgrowths of plasma;

- Rotifera - Rotariarotatoria - microscopic multicellular animals. Most of them can quite accurately be allocated a head region, a corpus and a leg;

- Fungi - fungi make an extensive group of organisms with absolutely special biological organization. The body of a mushroom consists of fine threads - the Hyphas forming the branched structure called mycelium. Hyphas represent the rigid tubules filled with multinuclear cytoplasm;

- Bacteria - the filamentous bacteria representing the lengthiest threads from rod cells connected together and covered with the common cover. Within the thread cells grow by ordinary division. Bacteria play the main role in removal and oxidation of organic and some inorganic compounds in sewage treatment and self-cleaning of water in natural reservoirs.

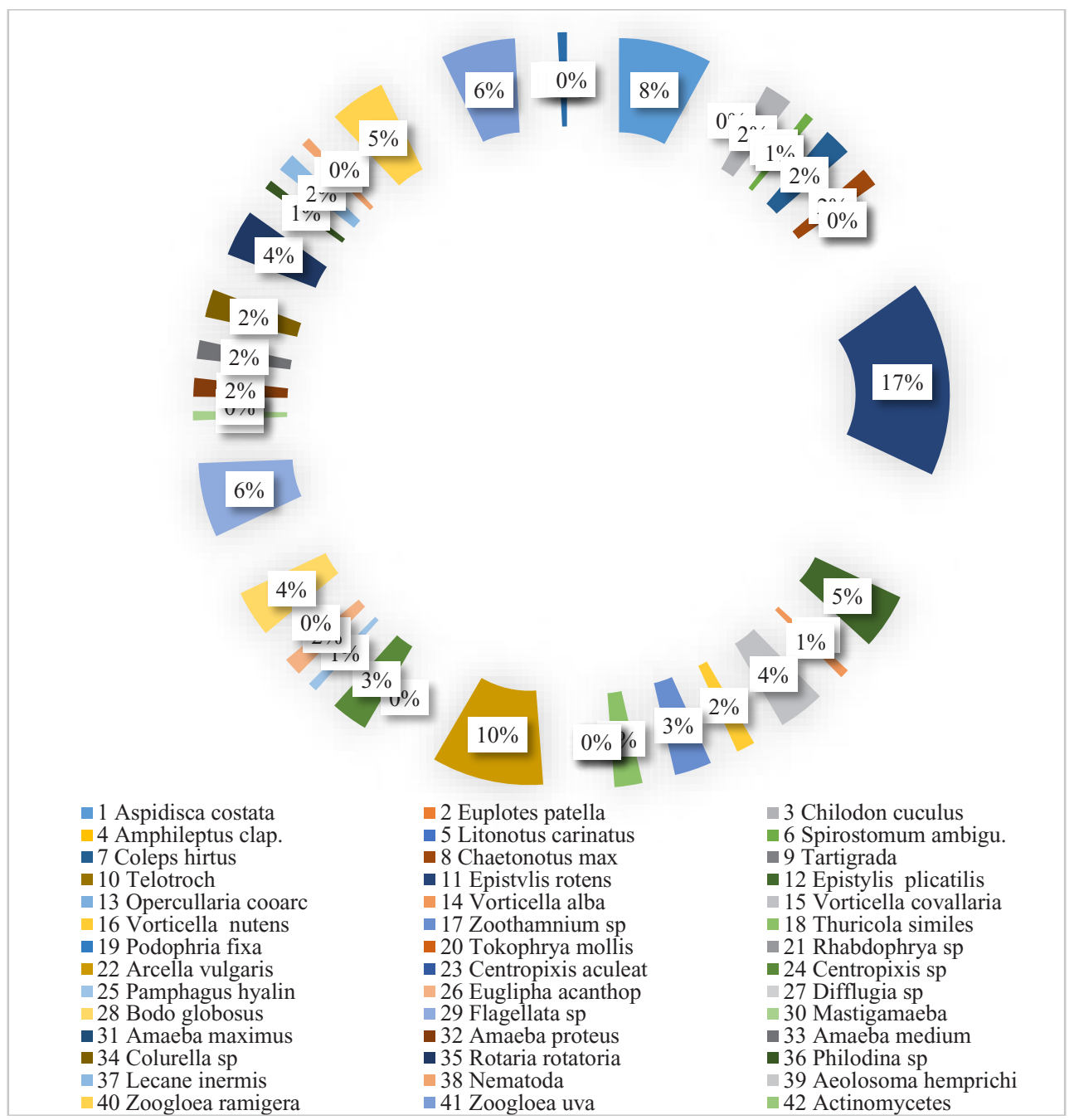

Fig. 1. Species composition of activated sludge on 26.06.2017. 
Fig. 2 presents the dynamics of development of microorganisms depending on medium factors.

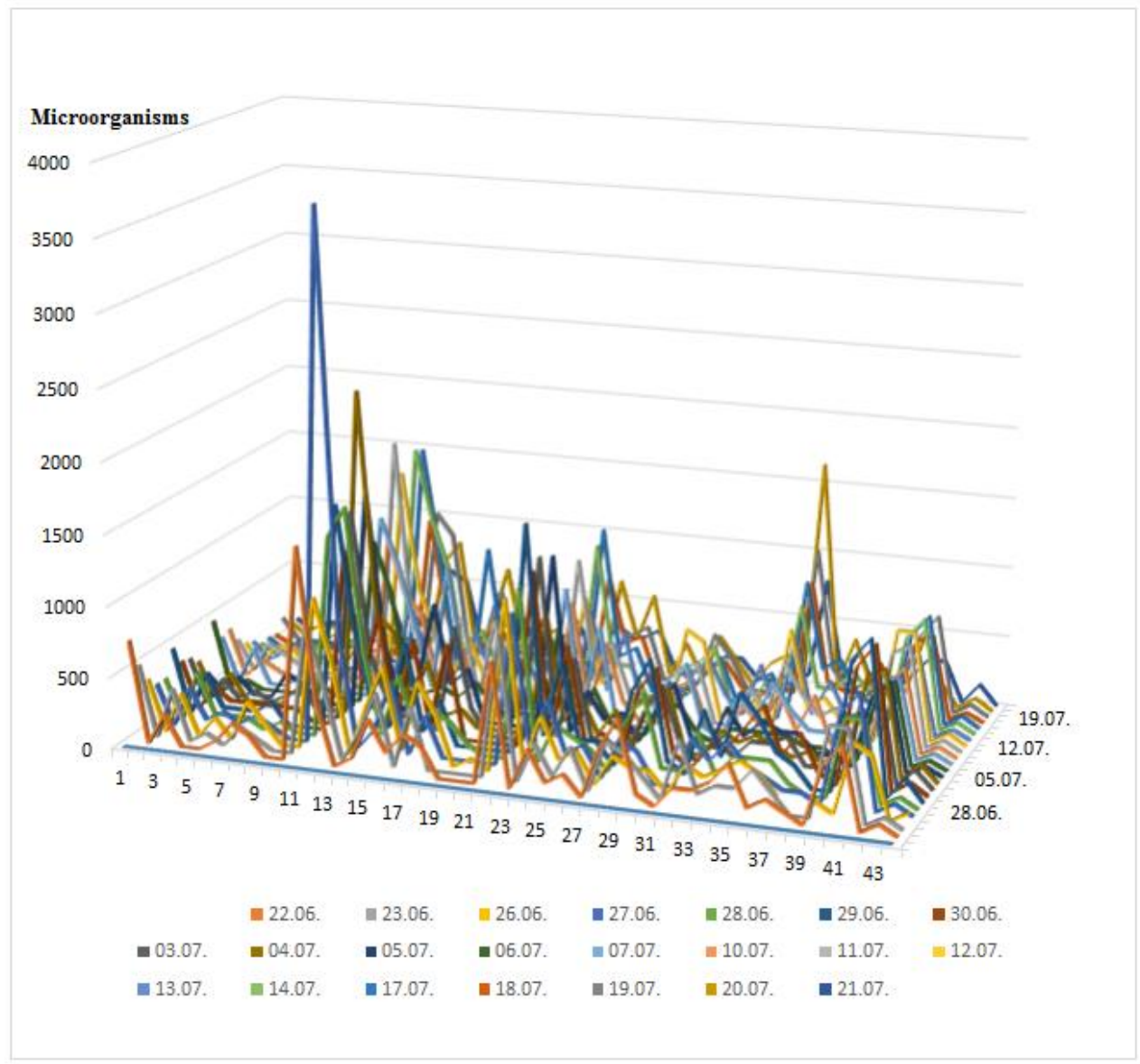

Fig. 2. Change of structure of microorganisms.

From graphs it is visible how within 21 days of carrying out an experiment the certain specific structure of activated sludge biocenosis was created.

Fig. 3 presents the daily discharge, a sludge dose and dissolved oxygen content during the experiment. It should be noted that the quantitative composition of microorganisms has a direct relation with the entering sewage flow rate.

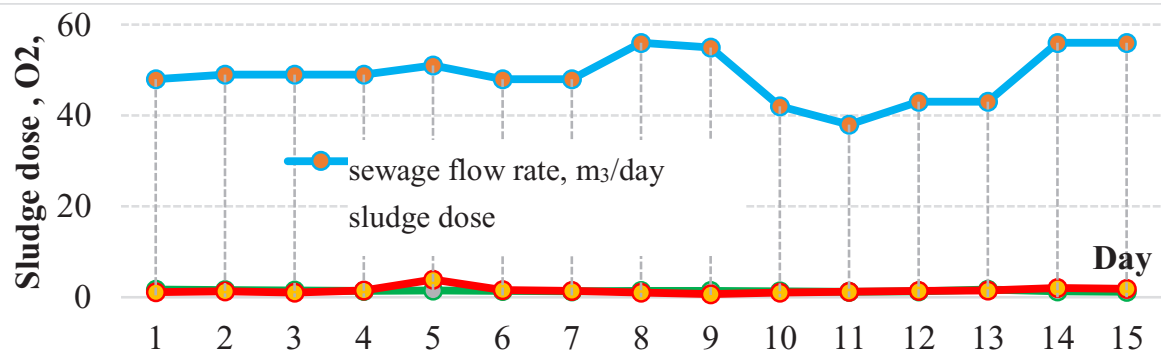

Fig. 3. Clear water characteristics on an expense, sludge dose and dissolved oxygen. 
After calculation of all microfauna, the following parameters are calculated: quantity of species, the ratio of the attached microorganisms to freely floating (coefficient K), percentage of susceptible microorganisms to persistent ones, the Cuba index (it includes the information, both about species quantity, and about their numerical distribution according to species) and quantity of microorganisms on a sludge dose (tab. 2.)

Table 2. Quantitative assessment of microorganisms in activated sludge.

\begin{tabular}{|c|c|c|c|c|c|c|}
\hline $\begin{array}{c}\text { Quality } \\
\text { of } \\
\text { species }\end{array}$ & $\begin{array}{c}\text { Coefficient } \\
\text { K }\end{array}$ & $\begin{array}{c}\text { Susceptible } \\
\text { microorganisms }\end{array}$ & $\begin{array}{c}\text { Coefficient } \\
\mathbf{1}\end{array}$ & $\begin{array}{c}\text { Coefficient } \\
\mathbf{2}\end{array}$ & $\begin{array}{c}\text { Sludge } \\
\text { dose }\end{array}$ & $\begin{array}{c}\text { Index } \\
\text { Cuba }\end{array}$ \\
\hline 8929 & 3000 & 3214 & 0,04 & 0,96 & 1,4 & 28,7 \\
\hline 8714 & 2571 & 3500 & 0,04 & 0,96 & 1,4 & 26,64 \\
\hline 9786 & 3786 & 3643 & 0,03 & 0,97 & 1,4 & 31,78 \\
\hline 12000 & 5429 & 3714 & 0,03 & 0,97 & 1,4 & 29,73 \\
\hline 11214 & 5000 & 3786 & 0,03 & 0,97 & 1,4 & 32,81 \\
\hline 13308 & 3769 & 5385 & 0,03 & 0,97 & 1,3 & 30,76 \\
\hline 12083 & 3917 & 4333 & 0,03 & 0,97 & 1,2 & 32,81 \\
\hline 10000 & 3500 & 3813 & 0,03 & 0,97 & 1,6 & 32,81 \\
\hline 9875 & 4438 & 3188 & 0,04 & 0,96 & 1,6 & 27,67 \\
\hline 9313 & 3750 & 3438 & 0,04 & 0,96 & 1,6 & 27,67 \\
\hline 7000 & 3000 & 2059 & 0,04 & 0,96 & 1,7 & 28,70 \\
\hline 10500 & 4500 & 3500 & 0,04 & 0,96 & 1,6 & 27,67 \\
\hline 8600 & 3533 & 2667 & 0,04 & 0,96 & 1,5 & 28,70 \\
\hline 10714 & 4143 & 3571 & 0,04 & 0,96 & 1,4 & 28,70 \\
\hline 9769 & 3462 & 3000 & 0,04 & 0,96 & 1,3 & 28,70 \\
\hline 6688 & 1750 & 2563 & 0,04 & 0,96 & 1,6 & 27,67 \\
\hline 11143 & 4571 & 3071 & 0,03 & 0,97 & 1,4 & 29,73 \\
\hline 10692 & 4154 & 2923 & 0,03 & 0,97 & 1,3 & 29,73 \\
\hline 7765 & 2588 & 2471 & 0,04 & 0,96 & 1,7 & 28,70 \\
\hline 8615 & 3154 & 2308 & 0,04 & 0,96 & 1,3 & 30,76 \\
\hline 9250 & 2917 & 3083 & 0,03 & 0,97 & 1,2 & 28,70 \\
\hline 5786 & 1929 & 1786 & 0,04 & 0,96 & 1,4 & 25,60 \\
\hline
\end{tabular}

As is seen from tab. 2 of the quantitative accounting of microorganisms, the activated sludge biocenosis has good species composition and all the indices are normal.

Fig. 4 and tab. 3, 4 present treatment effect of the following substances on exit from the aerotank: suspended substances, SS and oil products.

As is seen from the fig. 4, the treatment quality meets the requirements of maximum permissible discharge, except for the days when total suspended substances in clear water either strongly falls or strongly exceeds. In such cases, it's quite possible that activated sludge biocenosis lacks or has excess of nutrients that leads to deterioration in quality indices.

Table 3. Treatment quality of Suspended substances.

\begin{tabular}{|c|c|c|c|c|}
\hline Date & $\begin{array}{c}\text { SS } \\
\text { (clear water) }\end{array}$ & $\begin{array}{c}\text { SS } \\
\text { (renovated water) }\end{array}$ & Standard allowable value & $\begin{array}{c}\text { Sewage flow } \\
\text { rate, } \mathrm{m}^{3} / \text { day }\end{array}$ \\
\hline 21.06 .2017 & 121 & 6,6 & 10 & 55 \\
\hline 22.06 .2017 & 105 & 9,6 & 10 & 52 \\
\hline 23.06 .2017 & 117 & 8,2 & 10 & 52 \\
\hline 27.06 .2017 & 92 & 6,8 & 10 & 38 \\
\hline 28.06 .2017 & 60 & 22 & 10 & 52 \\
\hline 29.06 .2017 & 178 & 8,6 & 10 & 52 \\
\hline 30.06 .2017 & 120 & 4,6 & 10 & 45 \\
\hline 03.07 .2017 & 97 & 9 & 10 & 43 \\
\hline 04.07 .2017 & 198 & 8,4 & 10 & 68 \\
\hline 05.07 .2017 & 209 & 11,2 & 10 & 76 \\
\hline 06.07 .2017 & 136 & 10 & 10 & 51 \\
\hline
\end{tabular}




\begin{tabular}{|c|c|c|c|c|}
\hline 07.07 .2017 & 286 & 15,2 & 10 & 89 \\
\hline 10.07 .2017 & 154 & 9 & 10 & 61 \\
\hline 11.07 .2017 & 74 & 11,2 & 10 & 53 \\
\hline 12.07 .2017 & 119 & 8,6 & 10 & 48 \\
\hline 13.07 .2017 & 186 & 5,4 & 10 & 49 \\
\hline 14.07 .2017 & 161 & 6,4 & 10 & 49 \\
\hline 17.07 .2017 & 96 & 6,8 & 10 & 49 \\
\hline 18.07 .2017 & 163 & 5,6 & 10 & 51 \\
\hline 19.07 .2017 & 54 & 15,4 & 10 & 48 \\
\hline 20.07 .2017 & 76 & 14,2 & 10 & 48 \\
\hline
\end{tabular}

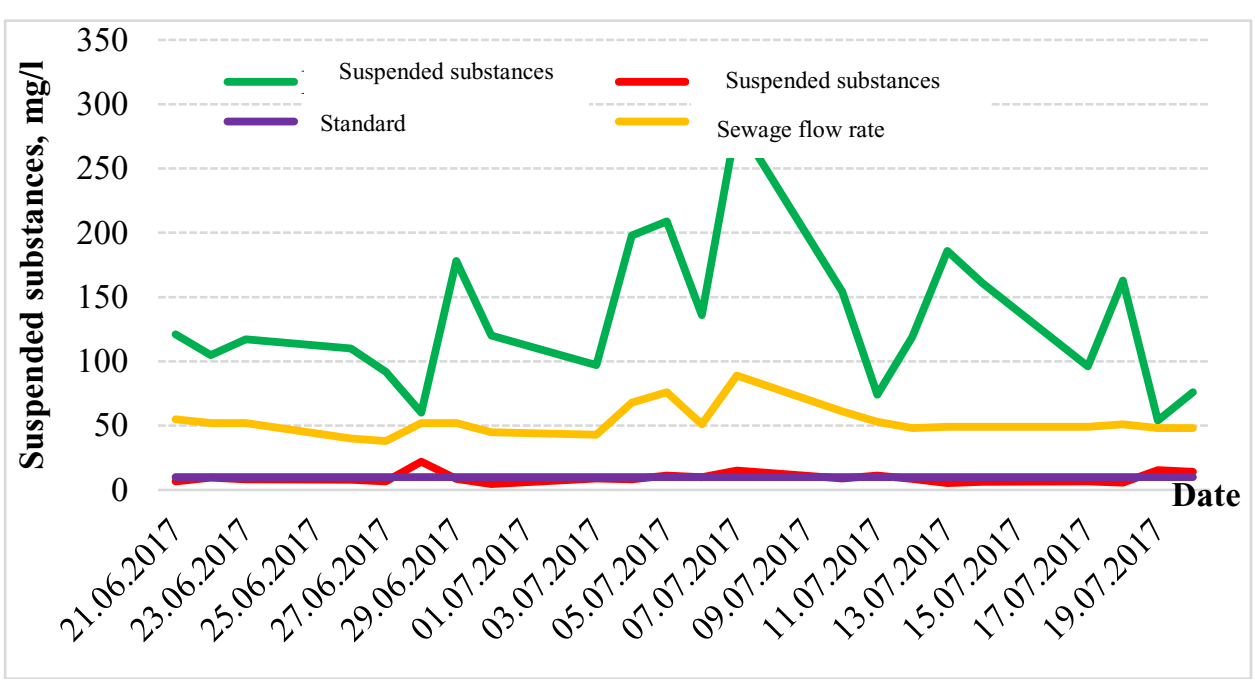

Fig. 4. Suspended substances treatment.

The quality of synthetic surfactants treatment in the given composition of activated sludge biocenosis is much lower than allowable discharge rate. In the review of literature we noted about the possibility of applying a biochemical method for textile production sewage renovation (immediately from boilery).

To achieve the same indices for oil products treatment, it is necessary to increase an activated sludge dose and dissolved oxygen concentration by $15-20 \%$. As is seen from tab. 4 , quality indices in renovated water on oil products slightly exceed allowable discharge.

Table 4. Synthetic Surfactants and oil products treatment quality.

\begin{tabular}{|c|c|c|c|c|c|c|}
\hline \multirow{2}{*}{ Date / time } & \multicolumn{3}{|c|}{ SS treatment quality } & \multicolumn{3}{c|}{ Oil products treatment quality } \\
\cline { 2 - 7 } & Clean water & Renovated water & Standard & $\begin{array}{c}\text { Clean } \\
\text { water }\end{array}$ & $\begin{array}{c}\text { Renovated } \\
\text { water }\end{array}$ & Standard \\
\hline $21.06 .2017 / 10-20$ & 2,8 & 0,06 & 0,5 & 2,4 & 0,07 & 0,05 \\
\hline $22.06 .2017 / 10-00$ & 2,4 & 0,046 & 0,5 & 1,7 & 0,07 & 0,05 \\
\hline $23.06 .2017 / 10-05$ & 1,9 & 0,055 & 0,5 & 2,2 & 0,06 & 0,05 \\
\hline $26.06 .2017 / 10-00$ & 2,5 & 0,067 & 0,5 & 2,4 & 0,09 & 0,05 \\
\hline $27.06 .2017 / 10-10$ & 2 & 0,057 & 0,5 & 2,8 & 0,07 & 0,05 \\
\hline $28.06 .2017 / 10-20$ & 2,4 & 0,069 & 0,5 & 2,6 & 0,06 & 0,05 \\
\hline $29.06 .2017 / 10-00$ & 2,6 & 0,049 & 0,5 & 2,8 & 0,05 & 0,05 \\
\hline
\end{tabular}




\begin{tabular}{|l|l|l|l|l|l|l|}
\hline $30.06 .2017 / 10-15$ & 2,2 & 0,051 & 0,5 & 1,9 & 0,08 & 0,05 \\
\hline $03.07 .2017 / 10-00$ & 2,7 & 0,074 & 0,5 & 2,1 & 0,12 & 0,05 \\
\hline $04.07 .2017 / 10-00$ & 1,9 & 0,045 & 0,5 & 2,4 & 0,09 & 0,05 \\
\hline $05.07 .2017 / 10-25$ & 3 & 0,071 & 0,5 & 2,4 & 0,12 & 0,05 \\
\hline $06.07 .2017 / 10-40$ & 2,3 & 0,064 & 0,5 & 2,6 & 0,11 & 0,05 \\
\hline $07.07 .2017 / 10-20$ & 2,1 & 0,06 & 0,5 & 2,3 & 0,09 & 0,05 \\
\hline $10.07 .2017 / 10-30$ & 2 & 0,073 & 0,5 & 2,7 & 0,08 & 0,05 \\
\hline $11.07 .2017 / 10-05$ & 2,5 & 0,058 & 0,5 & 2,5 & 0,06 & 0,05 \\
\hline $12.07 .2017 / 10-15$ & 2,1 & 0,068 & 0,5 & 2,3 & 0,07 & 0,05 \\
\hline $13.07 .2017 / 10-25$ & 1,7 & 0,054 & 0,5 & 3,7 & 0,09 & 0,05 \\
\hline $14.07 .2017 / 10-05$ & 2,6 & 0,055 & 0,5 & 2,9 & 0,07 & 0,05 \\
\hline $17.07 .2017 / 10-15$ & 3,1 & 0,068 & 0,5 & 3,5 & 0,15 & 0,05 \\
\hline $18.07 .2017 / 10-10$ & 2,2 & 0,059 & 0,5 & 3,4 & 0,08 & 0,05 \\
\hline $19.07 .2017 / 10-20$ & 2,1 & 0,061 & 0,5 & 2,7 & 0,08 & 0,05 \\
\hline $20.07 .2017 / 10-25$ & 2 & 0,063 & 0,5 & 2,3 & 0,09 & 0,05 \\
\hline $21.07 .2017 / 10-20$ & 2,6 & 0,049 & 0,5 & 2,5 & 0,07 & 0,05 \\
\hline
\end{tabular}

\section{Discussion}

The conducted researches showed that the removal of ammonium nitrogen and phosphorus pollution to standard allowable value in continuous-flow aerotanks without anaerobic zones is unattainable.

Organic matters in aquatic medium oppress nitrifying bacteria development, therefore nitrification begins only after oxidation of carboniferous organic compounds under the conditions of the first stage of nitrification. Nitrobacteria are also capable to accumulate polyphosphates in their cells. Normally, considering superficial nitrification and phosphates demand of bacteria, biological treatment removes from 10 to $30 \%$ of the dissolved phosphorus compounds. For developing nitrobacteria in retrofit designed aerotanks, it is possible to apply the attached microflora by means of various loadings and creation of anaerobic zones in one of the corridors, with the mixer and recycling of sludge mix in the construction head.

\section{Conclusion}

Increasing or reducing pollution inflow to the activated sludge makes possible artificial control of activated sludge biocenosis, its speed and pollution removal, that is, excess sludge quantity and treated sewage quality.

Thus, the research of activated sludge biocenosis on its development stages helps to determine the dominating forms of organisms in aerotanks working with different sludge loads. Smooth aerotank operating in activated sludge allows the constant biocenosis corresponding to a particular developmental stage. Biocenosis change demonstrates the change of aerotank operating mode.

Therefore, set loadings under which, process of biological loading will proceed in one or another developmental stage of activated sludge is of much interest. 


\section{References}

1. Recommendations on hydrobiological control of biological sewage treatment with aerotanks (OGU «Analiticheskiy tsentr» Publ., Perm, 2004)

2. E. Gogina, O. Yantsen, International of Applied Engineering Research 10(24), 44070 44074 (2015)

3. E.S. Gogina, O.V. Yantsen, O.A. Ruzhitskaya, V. Dabrovski, R. Zhilka, D.I. Boruzhko, Water and ecology 3, 35-46 (2016)

4. E.V. Alekseev, Physical and chemical sewage disposal (Izdatel'stvo Assotsiatsii stroitel'nykh vuzov Publ., Moscow, 2007)

5. M.N. Kozlov, A.G. Dorofeev, V.G. Aseeva, Microbiological monitoring of activated sludge of bioreactors for municipal waste water treatment from biogenic elements (Science Publ., 2012)

6. N.S. Zhmur, Technological and biochemical processes of cleaning of waste water treatment on aerotank constructions (AKVAROS Publ., Moscow, 2003) 